\title{
Vállalati stratégia a lineáris tevékenységelemzés modelljében
}

\section{Business strategy in the model of linear activity analysis of production}

\author{
I. BESSENYEI \\ Pécsi Tudományegyetem, Közgazdaságtudományi Kar, essenyei@ktk.pte.hu
}

\begin{abstract}
Absztrakt. Azt vizsgáljuk, hogy a lineáris tevékenységelemzés módszere mennyiben támogatja a különféle stratégiák vállalati bevezetését. Elemzésünk fókuszába a piaci nyitottságot, a lean menedzsmentet és a környezetvédelmi stratégiát helyezzük. Megmutatjuk, hogy a lineáris tevékenységelemzés, elsősorban a folyamatoptimalizálás problémájának hatékony megoldása révén, alkalmas a lean menedzsment döntéseinek támogatására, és további célkitüzések vállalati stratégiába illesztésére. Ilyen további célkitüzés lehet bizonyos termelési kultúrák megörzése a későbbi fejlesztés céljából, vagy bizonyos versenykorlátozó stratégiák követése. Megmutatjuk azt is, hogy az egyes stratégiai célkitüzések költsége miként számszerüsíthető a lineáris tevékenységelemzés modelljében.
\end{abstract}

Abstract. It was analyzed how the methodology of linear activity analysis of production model supports the implementation of different business strategies at a company level. Aspects of analysis are focusing on openness for markets, lean management and environmental protection strategies. The study reveals that the linear activity analysis of production - mainly due to its efficient process optimization problem solving ability - is capable supporting lean management decisions and implementing additional objectives in business strategies. Such objectives can be sustaining specific production patterns for further development or following strategies for limiting market competition. It will be shown how to quantify the costs of strategic objectives in linear activity analyzing model.

Jelen tanulmány célja annak vizsgálata, hogy a lineáris tevékenységelemzés Koopmans [2| által kifejlesztett modellje mennyiben alkalmas a vállalati döntések támogatására, különös tekintettel a lean menedzsment igényeire. Womack és Jones, [4| szerint a lean stratégia a vállalat által nyújtott érték meghatározása mellett az értékteremtő tevékenységek sorrendjének optimalizálását, az azok közti fölösleges szünetek minimalizálását, a vevői igények meghatározó szerepét, valamint a folyamatos fejlesztést helyezi a menedzsment fókuszába. Mivel a lineáris tevékenységelemzés modellje a termelőfolyamatok időbeliségét figyelmen kívül hagyja, az optimális sorrend és a fölösleges szünetek problémájával nem foglalkozunk. ${ }^{1}$ Vizsgálódásaink a kizárólag vevői igények által történő cselekvés stratégiai követelményén alapulnak, emellett azonban a piaci és technológiai nyitottság, valamint a környezetvédelem stratégiai szempontjai is központi szerepet kapnak.

${ }^{1}$ Ezekre a problémákra a CPM módszer ad megoldást. 
A tanulmány első része Zalai [5| nyomán a lineáris tevékenységelemzés modelljét adaptálja vállalati környezetbe. Ezt követi a túlspecializáció problémájának bemutatása, s a probléma több megoldási lehetőségének felvázolása. A harmadik szakasz részletesebben is bemutatja a környezetvédelem stratégiai célkitűzésének modellbe illesztését. A tanulmányt rövid összegzés zárja.

\section{A lineáris tevékenységelemzés modellje}

A vállalati értékteremtés a múszaki és szervezési szempontból lehetséges tevékenységek, vagy folyamatok ${ }^{2}$ eltérő intenzitású, azaz eltérő szintű alkalmazása révén megy végbe. Losonci [3| szerint a lean stratégia a vállalati pazarlást az értéket nem teremtő tevékenységek felszámolása révén szünteti meg. E tevékenységek alkalmazási szintje zérus. Látni fogjuk, hogy az ilyen tevékenységek kiválasztására a lineáris tevékenységelemzés modellje kiválóan alkalmas.

Egy tevékenység termékeket és/vagy szolgáltatásokat állít elő. Ennek során felhasznál a vállalat által előállított termékeket és szolgáltatásokat, továbbá a piacon vásárolt termékeket és szolgáltatásokat. Utóbbiakat elsődleges erőforrásoknak nevezzük, ilyen például a munka, vagy részletesebb elemzés esetén a különféle szakképzettséget igénylő munkafajták. (Ezen a ponton jelenik meg a lean menedzsment emberi oldala.) A rövidség érdekében a továbbiakban a vállalat által előállított szolgáltatásokat is termékeknek fogjuk nevezni, ha ez semmiféle zavart nem okoz.

Legyen a vállalatnak $n$-féle terméke, beleértve a félkész termékeket és termelési szolgáltatásokat is. Ezek előállításához használjon fel $N$-féle elsődleges erőforrást! Jelölje $R_{+}$a nemnegatív valós számok halmazát, ekkor egy alaptechnológia a következő három vektor segítségével írható le: $\mathbf{k} \in R_{+}^{n}$ a kibocsátási együtthatók, $\quad \mathbf{r} \in R_{+}^{n} \quad$ ráfordítási együtthatók, $\mathbf{d} \in R_{+}^{N} \quad$ pedig az elsődleges erőforrásfelhasználási együtthatók vektora. A három vektor elemei a tevékenység egységnyi szintű alkalmazása során szükséges, illetve előállított termék, illetve ráfordítási igényeket adják meg. A szóban forgó tevékenység intenzitása tetszőleges mértékegységben kifejezhető. Ez lehet például a tevékenység üzemeltetési ideje, vagy a tevékenység folytatásához felhasznált valamelyik elsődleges erőforrás (például villamosenergia) mennyisége.

Megjegyzendő, hogy a k vektornak többnyire egynél több pozitív eleme van, mert a legtöbb folyamat működése során a további feldolgozásra, vagy értékesítésre alkalmas termék mellett melléktermékek, hulladékok, illetve szennyezőanyagok is képződnek. Ha a k vektor minden eleme nulla, akkor a szóban forgó tevékenység célja a szennyezőanyagmentesítés. Ez azonban ritkán sikerül tökéletesen, ezért szinte mindig van néhány pozitív elem. A szennyezőanyagmentesítés erőforrásigényét ebben az esetben is az $\mathbf{r}$ és $\mathbf{s}$ vektorok számszerúsítik. Ha pedig a $\mathbf{k}$ vektornak több olyan pozitív eleme van, mely értékesítésre, vagy továbbfeldolgozásra alkalmas termék előállított mennyiségét jelzi, ikertermelésről beszélünk.

Legyen például a szóban forgó tevékenység a teherautóval történő anyagmozgatás. Ennek intenzitása mérhető az elszállított áru és a megtett távolság szorzatával (árutonnakilométer). Legyen továbbá az 1.

2 Ezeket a tevékenységeket, vagy folyamatokat Zalai [5] elemi, vagy alapeljárásoknak nevezi. 
termék az anyagmozgatás, szintén árutonnakilométerben mérve, a 2. termék pedig a széndioxid. A tevékenység hátrányos tulajdonsága, hogy egy árutonnakilométer szállítási teljesítmény előállítására meglehetősen magas széndioxidkibocsátás esik, azaz a $k_{2} / k_{1}$ arány magas. Alacsonyabb érték adódik egy alternatív tevékenység, például iparvasúton történő szállítás esetén.

Ha az $\mathbf{r}$ vektor valamennyi eleme zérus, akkor a szóban forgó tevékenység kizárólag elsődleges erőforrásokat használ fel, működtetéséhez a vállalat által előállított félkész termékekre, segédanyagokra, vagy szolgáltatásokra nincs szükség. Ritkábban fordul elő, hogy a d vektor áll csupa nullából, mert a legtöbb tevékenység felhasznál valamilyen elsődleges erőforrást.

A legtöbb vállalat természetesen egynél több tevékenységet képes folytatni. Legyen a műszaki és szervezési szempontból rendelkezésre álló tevékenységek száma $m$. Ezek mindegyike leírható az imént bevezetett három vektorral, és így az alábbi mátrixok állíthatók elő:

- Kibocsátási együtthatók mátrixa: $\mathbf{K}=\left(\mathbf{k}_{1}, \mathbf{k}_{2}, \ldots, \mathbf{k}_{m}\right)$, ahol $k_{i j}$ azt mutatja meg, hogy a $j$-edik tevékenység egységnyi szintű alkalmazása mennyit állít elő az $i$-edik termékből.

- Ráfordítási együtthatók mátrixa: $\mathbf{R}=\left(\mathbf{r}_{1}, \mathbf{r}_{2}, \ldots, \mathbf{r}_{m}\right)$, ahol $r_{i j}$ azt mutatja meg, hogy a j-edik tevékenység egységnyi szintű alkalmazásához mennyi szükséges az $i$-edik termékből.

- Elsődleges erőforrásfelhasználási együtthatók mátrixa: $\mathbf{D}=\left(\mathbf{d}_{1}, \mathbf{d}_{2}, \ldots, \mathbf{d}_{m}\right)$, ahol $r_{l j}$ azt mutatja meg, hogy a $j$-edik tevékenység egységnyi szintű alkalmazásához mennyi szükséges az $l$-edik elsődleges erőforrásból.

A lineáris tevékenységelemzés modelljében ez a három mátrix határozza meg a vállalat technológiai lehetőségeit. Elemeik pontos értékéről a műszaki menedzsment, illetve a mérnökök rendelkeznek információkkal, melyeknek összhangban kell állni a vállalat számviteli rendszeréből kinyerhető adatokkal.

Érdemes megjegyezni, hogy amennyiben a kibocsátási együtthatók mátrixának i-edik sorában egynél több pozitív elem van, akkor az $i$-edik terméket a vállalat több féle tevékenység révén is elő tudja állítani. Ilyenkor technológiai választékról beszélünk. A lineáris tevékenységelemzés feladata a lean menedzsment elveinek leginkább megfelelő technológiai kombináció kiválasztása.

Fogyasztásvezérelt rendszerünkben a vevői igényt az $\mathbf{y} \in R_{+}^{n}$ vektor írja le. Ennek elemei adják meg az egyes termékekből a készletezési pont számára előállítandó mennyiségeket. Azon félkész termékek, segédanyagok, illetve termelési szolgáltatások esetében, melyekre vevői igény nincs, az y vektor megfelelő eleme zérus, bár a vállalat többnyire ezeket is előállítja. Ugyanez a helyzet a hulladékok, vagy szennyezőanyagok esetében.

Ismert, hogy a lean menedzsment középpontjában a vevői értékteremtés áll. A lineáris tevékenységelemzés modelljében ez a fókusz kettős következménnyel jár. Egyrészt a vevő nem csupán a felesleges tevékenységekért nem hajlandó fizetni, de azon értékteremtő tevékenységek többletköltségét sem fizeti meg, melyeket más vállalatok hatékonyabban végeznek. Következésképp a vállalatnak nem csupán a vevők, hanem más vállalatok felé is nyitottnak kell lennie. Ez azt jelenti, hogy a félkész termékek, segédanyagok és termelési szolgáltatások saját előállítása mellett, vagy helyett ezek piacról történő beszerzését is lehetővé kell tenni. A házi előállítású termékek mellett tehát 
megjelennek a piacról beszerzett termékek. Ezek mennyiségét az u vektor írja le. Ha a vállalat nem rendelkezik elegendő kapacitással, előfordul, hogy az $i$-edik termékre $0<y_{i} \cdot u_{i}$. ez azt jelenti, hogy a vállalat a vevői igények egy részét nem saját termelés révén elégíti ki, hanem a piacon beszerzett készterméket bocsátja a vevő rendelkezésére. Általában azonban nem ez a helyzet, hanem $\forall i=1, \ldots, n: 0=y_{i} \cdot u_{i}$, azaz ha a vállalat valamilyen terméket a piacról vásárol, akkor ilyen terméket nem értékesít.

Másrészt az értékteremtés a pazarlások felszámolását is megköveteli. Ez nem csupán a pazarló tevékenységek megszüntetését követeli meg, de minden olyan melléktermék, hulladék, esetleg szennyezőanyag értékesítését is, melyek iránt fizetőképes piaci kereslet mutatkozik. Ezek szerint a többi vállalat irányába fenntartott piaci nyitottság a lean menedzsment szempontjából alapvető jelentőségű. Az ilyen módon értékesítésre kerülő termékek mennyiségét a z vektor írja le. Ebben a szakaszban feltesszük, hogy a díjmentes lomtalanítás lehetséges, vagyis az értékesíthetetlen hulladék, vagy szennyezőanyagok költségmentesen eltüntethetők a rendszerből. E föltevés feloldására csak a 3. szakaszban fog sor kerülni. A piaci nyitottság jegyében többnyire olyan termékeket értékesít a vállalat, melyek iránt vevői igény nem mutatkozik $\left(z_{i} \cdot y_{i}=0\right)$ és ezeket a termékeket a piacon nem is vásárolja $\left(z_{i} \cdot u_{i}=0\right)$. A továbbiakban látni fogjuk, hogy ez a nyitottság teremt kapcsolatot a piaci árak és a vevői igények kielégítésére előállított termékek árnyékárai között.

Feltesszük, hogy a piaci nyitottságból adódó lehetőségek kihasználása során a vállalat az árakat befolyásolni nem képes, és az egyes termékeket a $\mathbf{p}^{\mathrm{m}}$ vektor által leírt árakon szerezheti be, illetve a $\mathbf{p}^{\mathrm{e}}$ vektor által leírt árakon értékesítheti. Az általánosság érdekében feltesszük továbbá, hogy $\mathbf{p}^{\mathrm{e}} \leq \mathbf{p}^{\mathrm{m}}$. Mindezek alapján azt mondhatjuk, hogy a piaci nyitottságból adódó lehetőségek kihasználása során a vállalat $\mathbf{p}^{\mathrm{m}} \mathbf{u}-\mathbf{p}^{\mathrm{e}} \mathbf{z}$ mértékű veszteséget szenved el, melyet forgóeszközhitel felvétele révén finanszírozhat. A negatív veszteséget nyereségnek tekintjük, ami a forgóeszköz finanszírozási igényt csökkenti. Ennek nagyságát felülről a $d_{\mathrm{e}}$ érték korlátozza. $0<d_{\mathrm{e}}$ esetén megengedett, hogy a piaci nyitottságból adódó lehetőségek kihasználása során a vállalat a korlát mértékéig veszteséget szenvedjen el, $0>d_{\mathrm{e}}$ esetén nyereséget kell elérni, legalább a korlát által meghatározott mértékben. Ritkábban a $d_{\mathrm{e}}=0$ egyensúlyi kritériumot is előírják a vállalat számára.

Jelölje $\overline{\mathbf{s}}$ a vállalat rendelkezésére álló elsődleges erőforrások mennyiségét! Ide tartoznak többnyire az állóeszközök, gépek, berendezések és felszerelések, valamint a magasan képzett, vagy mély vállalatspecifikus ismeretekkel rendelkező dolgozók. Ezt az elsődleges erőforrásmennyiséget kell a vevői igények által meghatározott mértékben kiegészíteni. A kiegészítés szükséges mértékét az $\mathbf{S}$ vektor írja le. Általánosságban nem igaz $s_{i} \cdot \bar{s}_{i}=0$ fennállása, inkább a meglévő elsődleges erőforrások készletét kell bővíteni. Feltesszük, hogy a vállalat az erőforráspiacon nem rendelkezik erőfölénnyel. Ekkor az elsődleges erőforrások ára a vállalat által nem befolyásolható konstans, melyet a q vektor tartalmaz. Mivel a vevői igények adottak, profitját a vállalat csak a pótlólagosan beszerzendő elsődleges erőforrások költségének csökkentése révén növelheti. E költség nagyságát a qs skalárszorzat határozza meg. 
Az elmondottakat az alábbi lineáris programozási feladat foglalja össze:

$$
\begin{array}{rlrl}
\mathbf{x}, \mathbf{z}, \mathbf{s}, \mathbf{u} & \geq 0 & & \text { árnyékárak: } \\
\mathbf{R x}+\mathbf{y}+\mathbf{z} & \leq \mathbf{K x}+\mathbf{u} & \mathbf{p}=\left(p_{1}, p_{2}, \ldots, p_{n}\right) \\
\mathbf{D x}-\mathbf{s} & \leq \overline{\mathbf{s}} & \mathbf{w}=\left(w_{1}, w_{2}, \ldots, w_{l}\right) \\
\mathbf{p}^{\mathrm{m}} \mathbf{u}-\mathbf{p}^{\mathrm{e}} \mathbf{z} & \leq d_{\mathrm{e}} & \text { (U) } \\
-\mathbf{q s} & \rightarrow \max &
\end{array}
$$$$
\text { (LP-1P) }
$$

A feladat megoldása során adott

- a vállalat termelési technológiája: $\mathbf{K}, \mathbf{R}$ és $\mathbf{D}$ mátrixok,

- a vállalat elsődleges erőforrásokkal való ellátottsága: $\overline{\mathbf{s}}$

- a piaci nyitottságból adódó lehetőségek során maximálisan elérhető veszteség mértéke: $d_{\mathrm{e}}$

- az elsődleges erőforrások árai: q,

- a vállalat termékeinek beszerzési $\mathbf{p}^{\mathrm{m}}$ és értékesítési $\mathbf{p}^{\mathrm{e}}$ árai.

A feladat megoldása során kapjuk

- az egyes tevékenységek alkalmazási szintjét: $\mathbf{x}$,

- a pótlólagosan beszerzendő elsődleges erőforrások mennyiségét: $\mathbf{s}$,

- a piaci nyitottság révén beszerzésre, illetve értékesítésre kerülő termékek mennyiségét: $\mathbf{u}$ és $\mathbf{z}$,

- és az árnyékárakat: $\mathbf{p}, \mathbf{w}, v$

Az egyes feltételekhez tartozó árnyékárak értelmezése:

- Az egyes termékek árnyékára megmutatja, hogy a vevői igény adott termékből történő egységnyi csökkenése esetén mennyivel csökkenne a pótlólagosan beszerzendő elsődleges erőforrások költsége: $p_{i}=\partial \mathbf{q s} / \partial y_{i}$. Ha ez az érték kisebb, mint amennyit a vevő a szóban forgó termékért fizetni hajlandó, akkor a szóban forgó termék iránti vevői igény csak veszteséggel elégíthető ki.

- Az egyes elsődleges erőforrások árnyékára azt mutatja meg, hogy mennyivel csökkenne a pótlólagosan beszerzendő elsődleges erőforrások költsége, ha a vállalat a szóban forgó elsődleges erőforrásból egységnyivel többel rendelkezne: $w_{i}=\partial \mathbf{q s} / \partial \bar{s}_{i}$. Ha ez az érték nulla, akkor a szóban forgó elsődleges erőforrás pótlólagos beszerzése szükségtelen.

- A piaci nyitottság során képződő veszteség árnyékára megmutatja, hogy e veszteség egységnyi növekedése esetén mennyivel csökkenne a pótlólagosan beszerzendő elsődleges erőforrások költsége: $v=\partial \mathbf{q s} / \partial d_{\mathrm{e}}$.

A feladat megoldásához a GAMS szoftvert ajánljuk, melyet kifejezetten az ilyen jellegű, s a tanulmány további részében bemutatásra kerülő problémák megoldására fejlesztettek ki, s tantermi változata az internetről ingyenesen letölthető. 
Tekintettel a lean menedzsment emberi oldalára figyelembe kell venni, hogy minden tevékenység megszüntetése dolgozói, ennélfogva emberi érdekeket sért. Ezzel a problémával mélyebben nem foglalkozunk, arra azonban felhívjuk a figyelmet, hogy az $i$-edik tevékenység akkor felesleges, ha a feladat megoldásában $x_{i}=0$. Amennyiben tehát a vállalat célja a folyamatoptimalizálás, az ennek során elkerülhetetlenül kialakuló belső verseny eldöntését a lineáris tevékenységelemzés modellje hatékonyan támogatja.

A duális feladat megkonstruálásához felírjuk a szimplex táblázatot:

\begin{tabular}{|c|c|c|c|c|c|c|}
\hline & $\mathrm{x}$ & $\mathrm{S}$ & $\mathrm{u}$ & $\mathrm{z}$ & & \\
\hline $\mathbf{p}$ & $-(\mathbf{K}-\mathbf{R})$ & 0 & $-\mathbf{E}$ & $\mathbf{E}$ & $\leq$ & $-\mathbf{y}$ \\
\hline $\mathbf{w}$ & D & $-\mathbf{E}$ & 0 & 0 & $\leq$ & $\overline{\mathbf{S}}$ \\
\hline \multirow[t]{3}{*}{$v$} & 0 & 0 & $\mathbf{p}^{\mathrm{m}}$ & $\mathbf{p}^{\mathrm{m}}$ & $\leq$ & $d_{\mathrm{e}}$ \\
\hline & $\geq$ & $\geq$ & $\geq$ & $\geq$ & & \\
\hline & 0 & $-q$ & 0 & 0 & & \\
\hline
\end{tabular}

1. táblázat: Az LP-1 feladathoz tartozó szimplex táblázat

Ennek alapján a duális feladat már könnyen felírható:

$$
\begin{aligned}
\mathbf{p}, \mathbf{w}, v \geq & \\
\mathbf{p K} & \leq \mathbf{p R + w D} \quad(\mathbf{x}) \\
\mathbf{w} & \leq \mathbf{q} \\
\mathbf{p} & \leq v \mathbf{p}^{\mathrm{m}} \quad(\mathbf{s}) \\
\mathbf{p} & \geq v \mathbf{p}^{\mathrm{e}} \quad(\mathbf{z}) \\
\mathbf{w} \overline{\mathbf{S}}+v \cdot d_{\mathrm{e}}-\mathbf{p y} & \rightarrow \min
\end{aligned}
$$

(LP-1D)

Az egyes feltételek jobb oldalán, zárójelben a hozzájuk tartozó duális változókat tüntettük fel. A dualitásból következik, hogy a j-edik tevékenység akkor és csakis akkor fölösleges, ha $\mathbf{p k}_{j}<\mathbf{p r}_{j}+\mathbf{w d}{ }_{j}$, azaz a folytatása során képződött érték árnyékárakon számítva nem éri el a ráfordítások árnyékárakon számított nagyságát.

Az egyes termékek piaci árai és árnyékárai között fennálló összefüggések a duális feladatból adódnak. Tegyük fel egy pillanatra, hogy $\mathbf{p}^{\mathrm{m}}=\mathbf{p}^{\mathrm{e}}$ ! ekkor az árnyékárak a piaci árakkal egyenesen arányosak, $\mathrm{s}$ az arányossági tényező: $v$. Amennyiben $\mathbf{p}^{\mathrm{m}} \neq \mathbf{p}^{\mathrm{e}}$, akkor annak a terméknek az árnyékára melyet a vállalat vásárol, annak beszerzési árával lesz egyenesen arányos, amelyet pedig melléktermékként, vagy hulladékként értékesít, az eladási árával. Az arányossági tényező továbbra is $v$. Ha pedig 
$u_{i}+z_{i}=0$, tehát valamely terméket a vállalat nem vásárolja, és csak a vevői igények kielégítése céljából értékesíti, ennek árnyékárára $v p_{i}^{\mathrm{m}}<p_{i}<v p_{i}^{\mathrm{e}}$ teljesül.

Továbbá a primális és duális feladatok célfüggvényértékei megegyeznek, így teljesül a $-\mathbf{q s}=$ $\mathbf{w} \overline{\mathbf{s}}+v \cdot d_{\mathrm{e}}-\mathbf{p y}$ összefüggés. Ezt átrendezve a

$$
\mathbf{p y}=\mathbf{w} \overline{\mathbf{s}}+\mathbf{q} \mathbf{s}+v \cdot d_{\mathrm{e}}
$$

mérlegegyenlőséget kapjuk, melynek bal oldalán a vevői igények kielégítéséből származó bevétel áll. A jobb oldalon szereplő három tag a három költségelem, sorrendben a következők: meglévő elsődleges erőforrások árnyékárakon számított költsége, pótlólagosan beszerzésre kerülő erőforrások beszerzési áron számított költsége és a piaci nyitottság lehetőségének kihasználásából adódó veszteség. Az (1) mérlegegyenlőtlenségből következik, hogy nyereséget a vállalat nem ér el. Ez azért van így, mert feltevésünk szerint a vállalat nem rendelkezik piaci erőfölénnyel, vagy ha igen, azt az LP-1 feladat nem reprezentálja. Emiatt modellünk csupán folyamatoptimalizálást végez, tehát a fölösleges folyamatokat szelektálja ki.

Az (1) mérlegegyenlet lehetőséget ad $v$ mélyebb értelmezésére. Ehhez tegyük fel, hogy vállalatunk a $\mathbf{p}^{\mathrm{m}} \mathbf{u}-\mathbf{p}^{\mathrm{e}} \mathbf{z}$ veszteséget forgóeszközhitelből finanszírozza, $d_{\mathrm{e}}$ pedig az erre a célra rendelkezésre álló hitelkeret! Ezt a hitelkeretet addig érdemes növelni, míg az elsődleges erőforrások pótlólagos beszerzése során elért megtakarítás (qs csökkenése) a forgóeszközfinanszírozás költségét meg nem haladja. $v$ tehát az az összeg, melyet egységnyi többlet forgóeszközért a vállalat maximálisan fizetni hajlandó, azaz a forgóeszközfelhasználás belső megtérülési rátája. Ezek szerint $d_{\mathrm{e}}$ értékét addig érdemes növelni, míg a $v=1+r$ egyenlőség létre nem jön, ahol $r$ a forgóeszközhitel reálkamatlába. Mindezek alapján azt mondhatjuk, hogy $v$ értéke általában nem sokkal nagyobb egynél.

Termékoptimalizálásra akkor kerülhet sor, ha a vállalat a vevői igények kielégítése során piaci erőfölénnyel rendelkezik. ${ }^{3}$ Ebben az esetben azt is meg kell határozni, hogy az egyes termékek iránt mutatkozó vevői igények milyen mértékben kerüljenek kielégítésre. Modellünket ekkor az alábbi feltétellel kell kiegészíteni:

$$
\mathbf{p}=\mathbf{a}-\mathbf{B}(\mathbf{y}+\mathbf{z})
$$

ahol a az egyes termékek rezervációs ára. Ilyen áron lehetne az egyes termékeket értékesíteni, ha azokból a vállalat csupán egyetlen egységnyit állítana elő, s azt a vevők között árverésre bocsátaná. A B mátrix fóátlójában szereplő $b_{i i}$ elem azt mutatja meg, hogy mennyivel kell az $i$-edik termék árát

\footnotetext{
${ }^{3}$ A termékoptimalizálás érdekes esetét vizsgálja Andor [1] 2015-ben országos második helyezést elért TDK dolgozata.
} 
csökkenteni ahhoz, hogy egységnyivel többet lehessen belőle értékesíteni. A mellékátlóban szereplő $b_{i j}$ elem pedig azt mutatja meg, hogy mennyivel kell az i-edik termék árát csökkenteni akkor, ha a vállalat a j-edik termékből egységnyivel többet értékesít. $b_{i j}$ abban az esetben pozitív, ha a vevők képesek az $i$-edik terméket a j-edikkel helyettesíteni. (Ezt a jelenséget a marketingben termékkannibalizmusnak szokás nevezni.) Kiegészítő termékek esetén (például cipő és a hozzávaló cipőápoló) $b_{i j}$ értéke negatív.

A termékoptimalizálás bevezetésével a termékek ára a primál feladat változói közé kerül, a célfüggvény $\mathbf{p y}-\mathbf{q s} \rightarrow$ max alakot ölt, így a modell elveszti linearitását. Ennek következtében a duális probléma megoldása a Kuhn-Tucker-féle feltételek alapján adódik. Ezen a ponton azonban már túlmentünk a lineáris tevékenységelemzés modelljének keretein, ezért a duális feltételek felírását mellőzzük. Megjegyezzük azonban, hogy a GAMS szoftver nemlineáris problémák megoldására is alkalmas. Ennek során figyelembe kell azonban venni, hogy a GAMS outputja csupán egy lokális optimumot szolgáltat, ami nem feltétlenül esik egybe a globális optimummal. A probléma vállalati keretek közt történő kezelésére a későbbiekben visszatérünk.

\section{Túlspecializáció}

Az előző szakaszban bemutatott tevékenységoptimalizálás ugyan kiszelektálja a fölösleges folyamatokat, ám a lineáris tevékenységelemzési modell matematikai sajátosságai folytán gyakori, hogy ennek során úgymond túlzásokba esik. Egy lineáris programozási feladat optimális megoldásában ugyanis a pozitív változók száma nem haladhatja meg a feltételek számát. Szemügyre véve még egyszer az előző szakaszban bemutatott LP-1P lineáris programozási problémát, az abban szereplő döntési változókat az alábbi táblázatban foglalhatjuk össze:

\begin{tabular}{|l|l|l|l|l|}
\hline Változók: & $\mathbf{x}$ & $\mathbf{s}$ & $\mathbf{z}$ & $\mathbf{U}$ \\
\hline számuk: & $m$ & $l$ & $n$ & $N$ \\
\hline
\end{tabular}

2. táblázat Az LP-1P feladat változói

A feltételeket pedig az alábbi táblázatban:

\begin{tabular}{|l|l|l|l|}
\hline \multicolumn{2}{|l|}{ Feltételek: } & számuk: \\
\hline $\mathbf{R x}+\mathbf{y}+\mathbf{z}$ & $\leq$ & $\mathbf{K x}+\mathbf{u}$ & $N$ \\
\hline $\mathbf{D x}-\mathbf{s}$ & $\leq$ & $\overline{\mathbf{s}}$ & $L$ \\
\hline $\mathbf{p}^{\mathrm{m}} \mathbf{u}-\mathbf{p}^{\mathrm{e}} \mathbf{z}$ & $\leq$ & $d_{\mathrm{e}}$ & 1 \\
\hline
\end{tabular}

Most tegyük fel, hogy az optimális megoldás szerint a vevői igények kielégítésén túl a vállalat valamennyi termékéből értékesít (esetleg egy másik piacon), vagy vásárol. Tegyük fel azt is, hogy minden elsődleges erőforrásból pótlólagos mennyiséget kell beszereznie. Ez azt jelenti, hogy az $\mathbf{u}$ és $\mathbf{z}$ vektoroknak összesen $n$ pozitív elemük van, továbbá az $\mathbf{s}$ vektor valamennyi eleme is pozitív. Ekkor az 
x vektornak csupán egyetlen pozitív eleme lehet, ami azt jelenti, hogy a vállalat csupán egyetlen tevékenységet müködtet. Ezen túl csak annyi további tevékenységet működtethet a vállalat, ahány termék esetében nem használja ki a piaci nyitottságból esetlegesen fakadó előnyöket, vagy ahány elsődleges erőforrásból nem szerez be a meglévőnél többet. Ezek az életidegen feltételek gyakran túlspecializációt eredményeznek: a vállalat nem használja ki a piaci nyitottságból adódó feltételeket, vagy lemond bizonyos elsődleges erőforrások pótlólagos beszerzéséről, illetve a rendelkezésére álló technológiák egy részét nem hasznosítva, túlságosan kevés tevékenységet múködtet.

A túlspecializáció oka modellünk linearitása, így kézenfekvőnek tűnik a probléma oly módon történő megszüntetése, hogy nemlineáris modellre térünk át. Erre az előző szakaszban már láttunk is egy példát, amikor a tevékenységoptimalizálás mellé a termékoptimalizálást is bekapcsoltuk. Egy másik lehetőség, hogy az LP-1P feladatban szereplő

$$
\sum_{j=1}^{m} r_{i j} x_{j}+y_{i}+z_{i} \leq \sum_{j=1}^{m} k_{i j} x_{j}+u_{i} \text { termékmérleg helyett a } \sum_{j=1}^{m} r_{i j} x_{j}+y_{i}+z_{i} \leq f\left(\sum_{j=1}^{m} k_{i j} x_{j}, u_{i}\right)
$$

formát alkalmazzuk ${ }^{4}$, ahol $i=1, \ldots, n$, továbbá $f$ lineárisan homogén aggregálófüggvény, többnyire egy alkalmasan paraméterezett CES forma. Ebben az esetben a termékmérleg az alábbi:

$$
\sum_{j=1}^{m} r_{i j} x_{j}+y_{i}+z_{i} \leq\left[a\left(\sum_{j=1}^{m} k_{i j} x_{j}\right)^{-\beta}+(1-a)^{-\beta}\right]^{-\frac{1}{\beta}} \quad i=1, \ldots, n
$$

Az egyszerű összeadás helyett CES aggregáló formára történő áttérés mögött az a meggondolás rejlik, hogy a saját előállítású, illetve a más vállalatoktól beszerzett félkész termékek nem pontosan ugyanolyanok, így nem képesek egymást tökéletesen helyettesíteni. Ha egymás tökéletes helyettesítői, akkor a vállalat csupán két lehetőség közül választhat: ha a saját előállítás olcsóbb, a félkész terméket maga állítja elő, ellenkező esetben pedig a piacról szerzi be. Tökéletes helyettesítés hiányában a saját előállítás költségének beszerzési árhoz $\left(p_{i}^{\mathrm{m}}\right)$ viszonyított aránya határozza meg, hogy a szükséges mennyiség mekkora hányadát állítja elő a vállalat, s mekkora hányadát szerzi be a piacon.

A CES aggregálófüggvény különösen fontos paramétere $\beta$, mely a saját előállítású és más vállalatoktól beszerzett félkész termékek között fennálló helyettesítés rugalmasságát határozza meg a következő módon: $\sigma=1 /(1+\beta)$, ahol $\sigma$ a helyettesítés, elemi mikroökonómiából ismeret rugalmassága. Értéke itt azt mutatja meg, hogy a saját előállítás költségének beszerzési árhoz mért arányában bekövetkező egy százalékos emelkedésre miként reagál a saját előállítás piacról beszerzett mennyiséghez viszonyított aránya. A helyettesítés rugalmassága határozza meg tehát, hogy a „Termeljük, vagy vásároljuk?" kérdés megválaszolása során milyen erőteljesen reagál a vállalat a piaci környezetben bekövetkező változásokra. Mint láthatjuk, e reakció erőssége attól függ, hogy milyen mértékben

${ }^{4}$ A jobb követhetőség érdekében az LP-1 feladatok felírásánál alkalmazott mátrix-forma helyett itt a skaláris felírást választottuk. 
képesek a piacról beszerzésre kerülő termékek a saját előállításúakat helyettesíteni. $\sigma$ értékét általában szakértői (mérnöki) becsléssel szokták meghatározni, ez többnyire egységnyinél nagyobb.

A CES függvény termékmérlegbe történő bevezetése esetén modellünk éppúgy elveszti linearitását, mint a (2) keresleti rendszer bevezetése nyomán, így a túlspecializáció problémája megoldható. Az elmondottakból azonban nem következik, hogy a túlspecializáció megoldásához ki kellene lépni a lineáris tevékenységelemzési modell keretei közül. A továbbiakban bemutatunk néhány olyan vállalati stratégiát, melyek bevezetése a lineáris tevékenységelemzési modell kereteit nem feszíti szét, ugyanakkor megoldást jelent a túlspecializáció problémájára.

Az előző szakaszban, a lean emberi oldalával kapcsolatban említettük, hogy a fölösleges tevékenységek megszüntetése többnyire dolgozói érdekeket sért, így a tevékenységoptimalizálás gyakran erős szervezeti ellenállásba ütközik. Ezért a tevékenységoptimalizálás során gyakran célszerű, esetenként elkerülhetetlen a „Ne fordítsuk fel fenekestől a vállalatot!” elvét követni. A gyakorlatban ez azt jelenti, hogy korlátozzuk a tevékenységoptimalizálás előtt fennálló indulóhelyzettől történő eltérés mértékét. Jelölje $\overline{\mathbf{x}}$ az egyes tevékenységek intenzitását a tevékenységoptimalizáció előtt, $\mathbf{r}^{\mathrm{x}}$ pedig a tevékenységoptimalizáció során ettől bármilyen irányban történő relatív eltérés legnagyobb megengedett nagyságát, majd képezzük az alábbi diagonális mátrixot:

$$
\left\langle\mathbf{r}^{\mathrm{x}}\right\rangle=\left(\begin{array}{cccc}
r_{1}^{\mathrm{x}} & 0 & \ldots & 0 \\
0 & r_{2}^{\mathrm{x}} & \ldots & 0 \\
\vdots & \vdots & \ddots & \vdots \\
0 & 0 & \ldots & r_{n}^{\mathrm{x}}
\end{array}\right)
$$

Modellünket most a következő feltételekkel egészítjük ki: $\left\langle\mathbf{E}-\mathbf{r}^{\mathrm{x}}\right\rangle \overline{\mathbf{x}} \leq \mathbf{x} \leq\left\langle\mathbf{E}+\mathbf{r}^{\mathrm{x}}\right\rangle \overline{\mathbf{x}}$. Az újonnan bevezetett feltételekhez tartozó árnyékárak ebben az esetben a vállalat tevékenységoptimalizálással szembeni rugalmatlanságának árát adják meg elsődleges erőforrásköltségben kifejezve. Megjegyzendő továbbá, hogy a szervezet belső stabilitásra törekvésének ilyen módon történő figyelembevételével a globális versus lokális optimum problémája veszít jelentőségéből, hisz az optimális megoldást a GAMSnek csak az aktuális tevékenységkombináció $\mathbf{r}^{\mathrm{x}}$ által meghatározott környezetében kell keresnie. Így kisebb a valószínűsége, hogy globális optimum helyett csupán lokálisat talál.

További stratégiai célkitűzése lehet a vállalatnak bizonyos termelési kultúrák fenntartása abban az esetben is, ha az ezeket szolgáló tevékenységek a versenytársakéhoz képest kevésbé hatékonyak. Ebben az esetben a (4) egyenletben szereplő diagonális mátrixhoz hasonlóan képzett $\left\langle\mathbf{r}^{\mathrm{mf}}\right\rangle$ mátrix főátlójában álló elemek a piaci beszerzés és saját előállítás maximálisan megengedett arányát adják, s a lineáris tevékenységelemzési modellt most az $\mathbf{u} \leq\left\langle\mathbf{r}^{\mathrm{mf}}\right\rangle \mathbf{K} \mathbf{x}$ feltételekkel egészítjük ki. Ha ilyen korlátozást az $i$-edik termék esetében nem szükséges tenni, a GAMS programban az $r_{i}^{\mathrm{mf}}$ paraméter inf értéket kap, ami arra utal, hogy $r_{i}^{\mathrm{mf}}$ tetszőlegesen nagy lehet. Éppígy stratégiai célkitűzés lehet bizonyos tevékenységek korlátozása. Ekkor modellünket az $\mathbf{u} \geq\left\langle\mathbf{r}^{\mathrm{ma}}\right\rangle \mathbf{K x}$ feltételekkel egészítjük ki, 
ahol $r_{i}^{\mathrm{ma}}$ a piaci beszerzés saját előállításhoz viszonyított minimális arányát adja meg az $i$-edik termékből. Az egyes feltételekhez tartozó árnyékárak ebben az esetben is az elsődleges erőforrások költségében fejezik ki a stratégia követésének árát.

Előfordulhat, hogy piaci erőfölényét oly módon növeli a vállalat, hogy versenytársaival kartellmegállapodást köt, melyben vállalja, hogy bizonyos elsődleges erőforrások felvásárolt mennyiségét korlátozza. Ebben az esetben az elsődleges erőforrásokat azok árnyékáránál alacsonyabban szerezheti be, vagy az így képződő veszteséget a kartell többi tagja kompenzálja. Az ilyen versenykorlátozó stratégia az $\mathbf{s} \leq \mathbf{s}^{\mathrm{f}}$ feltétel révén vezethető be a lineáris tevékenységelemzés modelljébe. Az $\mathbf{s}^{\mathrm{f}}$ vektor a kvótaszerződésben rögzített mennyiségeket tartalmazza. Az így bevezetett feltételekhez tartozó árnyékárak ezúttal is a kartellszerződés betartásának árát perprezentálják.

\section{Környezetkímélő stratégia}

A legtöbb tevékenység a továbbfelhasználásra, vagy vevői igények kielégítésére alkalmas termékek mellett a környezetre káros hulladék-, vagy szennyezőanyagokat is kibocsát. Jelölje $\overline{\mathbf{y}}$ az egyes termékekből maximálisan kibocsátható, ám értékesítésre nem kerülő termékek mennyiségét! Az ebben szereplő nagyságokat mind a vállalat környezetvédelmi stratégiája, mind pedig a környezetvédelmi hatóság meghatározhatja. Ha nincs díjmentes lomtalanítás, akkor az (LP-1P) modellben szereplő termékmérlegben az egyenlőtlenség helyére egyenlőség kerül, továbbá be kell vezetni a $(\mathbf{K}-\mathbf{R}) \mathbf{x}-\mathbf{y}-\mathbf{z} \leq \overline{\mathbf{y}}$ új feltételt. A bal oldalon álló első tag a vállalat egyes termékekből képződő nettó kibocsátása, ami a bruttó kibocsátás és a termelő felhasználás különbsége. Ebből ki kell vonni a vevői igények kielégítéséhez szükséges termékmennyiséget, továbbá azt, ami a többi vállalat felé értékesítésre kerül. Valószínű, hogy azon termékek esetében ahol a jobb oldalon álló korlát effektív, azaz végtelennél kisebb, az y vektorban zérus szerepel, hisz aligha mutatkozik vevői igény hulladék,- vagy szennyezőanyagok iránt. Ha azonban egy másik vállalat képes ezeket feldolgozni, akkor a $\mathbf{z}$ vektornak lehet pozitív eleme. Annál könnyebb ${ }^{5}$ a környezetvédelmi stratégiát követni, minél több ilyen eleme van a $\mathbf{z}$ vektornak, s azok minél nagyobbak.

A primál feladat most a következő:

\begin{tabular}{|c|c|c|c|}
\hline & $\mathbf{x}, \mathbf{z}, \mathbf{s}, \mathbf{u}$ & $\geq$ & 0 \\
\hline (p) & $\mathbf{R x}+\mathbf{y}+\mathbf{z}$ & $=$ & $\mathbf{K} \mathbf{x}+\mathbf{u}$ \\
\hline (w) & $\mathbf{D x}-\mathbf{s}$ & $\leq$ & $\overline{\mathbf{S}}$ \\
\hline (v) & $\mathbf{p}^{\mathrm{m}} \mathbf{u}-\mathbf{p}^{\mathrm{e}} \mathbf{z}$ & $\leq$ & $d_{\mathrm{e}}$ \\
\hline
\end{tabular}

${ }^{5}$ Ez azt jelenti, hogy a környezetvédelmi stratégia követése annál kevésbé költséges. Ez a duális feladatból egyértelműen ki fog derülni. 


$$
\begin{aligned}
\left(\mathbf{t}^{\mathrm{y}}\right)(\mathbf{K}-\mathbf{R}) \mathbf{x}-\mathbf{y}-\mathbf{z} & \leq \overline{\mathbf{y}} \\
-\mathbf{q S} & \rightarrow \text { Max }
\end{aligned}
$$

(LP-2P)

Az egyes feltételekhez tartozó duális változókat a feltételek előtt tüntettük fel. Ha az (LP-2P) a feladat optimális megoldásában $x_{i}>0$, de az (LP1-P) feladatéban $x_{i}=0$, akkor az $i$-edik folyamat szükséges, nem értékteremtő tevékenység és a környezetkímélő stratégia bevezetése révén vált szükségessé. A modellben újonnan megjelenő $t_{i}^{\mathrm{y}}$ árnyékárak az i-edik termék, mint szennyező-anyagkibocsátás korlátozásának árát adják meg, továbbra is az elsődleges erőforrások költségében kifejezve.

A duális feladat felírásához érdemes ezúttal is megadni a szimplex táblázatot:

\begin{tabular}{c|cccc|c} 
& $\mathbf{x}$ & $\mathrm{s}$ & $\mathrm{u}$ & $\mathrm{z}$ \\
$\mathbf{p}$ & $-(\mathbf{K}-\mathbf{R})$ & 0 & $-\mathbf{E}$ & $\mathbf{E}$ & $=-\mathbf{y}$ \\
$\mathbf{w}$ & $\mathbf{D}$ & $-\mathbf{E}$ & 0 & 0 & $\leq \overline{\mathbf{s}}$ \\
$v$ & 0 & 0 & $\mathbf{p}^{\mathrm{m}}$ & $\mathbf{p}^{\mathrm{e}}$ & $\leq d_{\mathrm{e}}$ \\
$\mathbf{t}^{\mathrm{y}}$ & $\mathbf{K}-\mathbf{R}$ & 0 & 0 & $-\mathbf{E}$ & $\leq \mathbf{y}+\mathbf{\mathbf { y }}$ \\
& $\geq$ & $\geq$ & $\geq$ & $\geq$ & \\
\cline { 2 - 6 } & 0 & $-\mathrm{q}$ & 0 & 0 &
\end{tabular}

4. táblázat: Az LP-2 feladathoz tartozó szimplex táblázat

Ennek segítségével az (LP2-P)-hez tartozó duális feladat már könnyen felírható:

$$
\begin{array}{lll}
\mathbf{w}, \mathrm{v}, \mathbf{t}^{\mathrm{y}} & 0 \\
\mathbf{p K} & \leq \mathbf{p R}+\mathbf{w D}+\mathbf{t}^{\mathrm{y}}(\mathbf{K}-\mathbf{R}) \\
\mathbf{w} & \leq \mathbf{q} \\
\mathbf{p} & \leq v \mathbf{p}^{\mathrm{m}} \\
\mathbf{p} & \geq v \mathbf{p}^{\mathrm{e}}+\mathbf{t}^{\mathrm{y}} \\
\mathbf{w} \overline{\mathbf{S}}+v \cdot d_{\mathrm{e}}+\mathbf{t}^{\mathrm{y}}(\mathbf{y}+\overline{\mathbf{y}})-\mathbf{p y} & \rightarrow \operatorname{Min}
\end{array}
$$

(LP-2D)

A dulális változók itt a feltételek után állnak. Érdemes felhívni a figyelmet, hogy primális feladatban szereplő egyenlőségfeltétel miatt a $\mathbf{p}$ változók előjelére semmiféle megkötést nem teszünk. Így bizonyos termékek árnyékára negatív is lehet. Az utolsó két feltétel szerint azonban ehhez az szükséges, hogy a szóban forgó termék piaci ára negatív legyen. Pontosan ez a helyzet a 
szennyezőanyagok esetében, hisz ezeket vállalatunk negatív áron vásárolhatja, azaz átvételükért az eladó fizet. Ebben az esetben vállalatunk végzi az átvett szennyezőanyag lerakását, feldolgozását, vagy megsemmisítését. Ha ilyen tevékenységet vállalatunk nem végez, akkor a megsemmisítendő szennyezőanyagokat más vállalatok részére átadhatja. Ebben az esetben azonban vállalatunk fizet azok átvételéért.

A dualitás miatt optimális megoldás esetén (LP2-P) és (LP2-D) célfüggvényértékei továbbra is megegyeznek, így $\mathbf{w} \overline{\mathbf{s}}+v \cdot d_{\mathrm{e}}+\mathbf{t}^{\mathrm{y}}(\mathbf{y}+\overline{\mathbf{y}})-\mathbf{p y}=-\mathbf{q s}$. Ebből a következő mérlegegyenlet adódik:

$$
\left(\mathbf{p}-\mathbf{t}^{\mathrm{y}}\right) \mathbf{y}=\mathbf{w} \overline{\mathbf{s}}+\mathbf{q s}+v \cdot d_{\mathrm{e}}+\mathbf{t}^{\mathrm{y}} \overline{\mathbf{y}}
$$

$\mathrm{Az}$ (5) egyenlet bal oldalán továbbra is az árnyékáron számított árbevétel szerepel. Ezt a szennyezőanyagok termelése csökkenti, de csak abban az esetben, ha azok kibocsátása a környezetvédelmi stratégia által meghatározott korlátba ütközik. Az (LP-2D) feladatban a z duális változókhoz tartozó feltételekből látszik, hogy a más vállalatok számára értékesített hulladék, vagy melléktermék árnyékára nem áll feltétlenül egyenes arányban e termék piaci értékesítési árával. A dualitás miatt, ha az i-edik termék kibocsátása a vállalat környezetvédelmi stratégiája által meghatározott korlátba ütközik, azaz $t_{i}^{\mathrm{y}}>0$, akkor e termék ára a $v \mathbf{p}^{\mathrm{e}}$ értéket meghaladja. Ha tehát az ilyen hulladék, vagy melléktermék iránt vevői igény mutatkozik, akkor ennek árát, az árnyékárakon számított árbevétel meghatározása során, $t_{i}^{\mathrm{y}}$-nal csökkenteni kell. Ezt fejezi ki az (5) mérlegegyenlet bal oldalán a zárójelben álló tényező. Jobb oldalon továbbra is az 1. szakaszban felsorolt költségelemek állnak, kiegészítve a környezetvédelmi stratégia követésének költségeivel. Ha az (LP-1) és (LP-2) feladatok optimális megoldása azonos, akkor a környezetvédelmi stratégia bevezetése hatástalan. Ekkor $\mathbf{t}^{\mathrm{y}}=0$, így az (5) egyenlet utolsó tagja zérus, és az árnyékára és piaci ár közti egyenes arányosság fennáll. Ha azonban az LP-1 feladat optimális megoldásában $x_{j}=0$, míg az LP-2 feladat optimális megoldásában $x_{j}>0$, akkor a $j$-edik folyamat a lean menedzsment terminológiája szerint szükséges, de nem értékteremtő tevékenység.

\section{Következtetések}

Dolgozatunkban a lineáris tevékenységelemzés módszerének néhány alkalmazási lehetőségét mutattuk be a stratégiai tervezés vállalati gyakorlatában. Az 1. szakaszban megmutattuk, hogy a módszer hatékonyan alkalmazható a lean menedzsmentben, elsősorban a folyamat-, vagy tevékenységoptimalizálás során. A módszer a termékoptimlizálásra is kiterjeszthető, ebben az esetben azonban az alkalmazott modellelveszti linearitását. Az ebből fakadó nehézségekre röviden rámutattunk.

A linearitásból adódó túlspecializáció kapcsán a 2. szakaszban megmutattuk, miként vezethető be a modellbe a saját előállítású és piacon vásárolt félkész termékek, segédanyagok, illetve szolgáltatások 
megkülönböztetése egyetlen terméken, vagy termékcsoporton belül. Ugyanitt röviden szemügyre vettük, miként építhető be a modellbe a vállalati szervezet stabilitásra törekvéséből adódó rugalmatlanság, vagy a vállalatnál meglévő egyes termelési kultúrák megőrzésének, illetve korlátozásának stratégiai célkitűzése. Röviden kitértünk a versenykorlátozó stratégia modellbe illesztésére is. Láttuk, hogy ezek a stratégiai célkitűzések minden nehézség nélkül beilleszthetők a lineáris tevékenységelemzés modelljébe.

A 3. szakaszban részletesen szemügyre vettük a környezetvédelmi célkitűzések lineáris tevékenységelemzés modelljébe történő beillesztésének lehetőségeit és következményeit. Megmutattuk, hogy az árnyékárak a stratégia követésének költségeit számszerűsítik. Ez az oka annak, hogy a primál feladatok mellett a hozzájuk tartozó duális feladatoknak is komoly figyelmet szenteltünk.

\section{Hivatkozások}

[1] K. Andor (2015), A vállalatok termékminőségbeli kínálatának optimalizálása LTM modell segítségével, Pécsi Tudományegyetem, Közgazdaságtudományi Kar

[2] T. Koopmans (1951), Analysis of production as an efficient combination of activities, In: Koopmans T. (szerk.) Activity Analysis of Production and Allocation. John Wiley and Sons, New York

[3] D. Losonci (2010), Bevezetés a lean menedzsmentbe - a lean stratégiai alapjai, Budapesti Corvinus Egyetem, Vállalatgazdaságtan Intézet, Műhelytanulmányok sorozat, 119.

[4] J. P. Womack, D. T. Jones (2003), Lean thinking - Banish waste and create wealth in your corporation, Simon\&Schuster UK Ltd

[5] E. Zalai (2012), Matematikai közgazdaságtan II. - Többszektoros modellek és makrogazdasági elemzések, Akadémiai Kiadó, Budapest 